\title{
Paleoenvironmental and stratigraphic investigations of the foraminiferal fauna from the Karpatian (Lower Miocene) Garáb Schlier Formation of the Mátraverebély-122 (Mv-122) borehole (North Hungary)
}

\author{
András Szabolcs Sóron \\ Department of Physical and Applied Geology, \\ Eötvös Loránd University, Budapest
}

\begin{abstract}
The Garáb Schlier Formation is composed of gray sand, silt, clay and clay marl, deposited in an open marine environment. The aims of this study were to reconstruct its paleoenvironmental features and to propose a hypostratotype of the Garáb Schlier Formation. Eighty-seven samples from the Mv122 borehole (between $177.0-698.0 \mathrm{~m}$ ) provided a dataset for detailed qualitative and quantitative analysis. The benthic and planktonic foraminiferal fauna were studied together. The associations indicated three different environments in the section. The lower part of the section records deposition in a normal marine, cool, outer shelf environment. Later on conditions changed to an upper bathyal, normal salinity, cool environment without permanent currents. Assemblages from the upper part of the section suggest that the water depth decreased and an inner shelf, normal salinity sea is inferred, with fluvial influence and open marine connections. The age of the sediment is Late Karpatian (Latest Burdigalian) as indicated by the M4b Planktonic Foraminifera Zone. The middle part of the studied section (337.0-664.0 m) is proposed here as the hypostratotype of the Garáb Schlier Formation.
\end{abstract}

Keywords: Foraminifera, paleoecology, Karpatian, Garáb Schlier Formation, hypostratotype, North Hungary

\section{Introduction}

Immature, mixed sandy-silty siliciclastic marine deposits derived from the emerging Carpathians are widespread in the northern part of the Pannonian Basin. Referred to as "schlier" based on their characteristic lithology and biofacies (Báldi 1986), they are typical formations in the Miocene stratigraphy of the area. Surface outcrops of these several hundred meter thick, but recessive units are widely scattered. However, much useful information can be obtained from cores,

Address: $\quad$ A. Sz. Sóron: H-1117 Budapest, Pázmány P. sétány 1/c, Hungary e-mail: soron.andras@gmail.com

Received: December 22, 2010; accepted: April 22, 2011 
as numerous boreholes were drilled through these strata in the coal-bearing basins.

This paper reports a qualitative and quantitative analysis of foraminiferal fauna from borehole Mv-122 and considers this section as an alternative (hypo) stratotype of the Karpatian Garáb Schlier Formation (Csepreghyné Meznerics 1951). The current stratotype of the formation (Garáb [Felsőtold] 1 borehole) was established and described by Hámor (1985) but that borehole did not penetrate through the entire Garáb Schlier Formation.

Present-day North Hungary was part of the Central Paratethys Basin (Fig. 1) from the Late Eocene to the Middle Miocene (Báldi 1980; Hámor 1985, 2001, 2007; Nagymarosy 2000). The Paratethys had special paleoenvironmental and sedimentary characteristics due to intermittent connections with the Mediterranean region (Rögl 1999). In the Karpatian (late Early Miocene) the Central Paratethys was connected to the Mediterranean realm through the Slovenian Corridor (Fig. 1) (Rögl 1999; Kováč et al. 2003).

Hantken (1878) separated this lithological unit from the surrounding formations. Noszky $(1912,1914)$ defined these strata as schlier and in 1929 he separated this one from the other North Hungarian schlier units. Csepreghyné

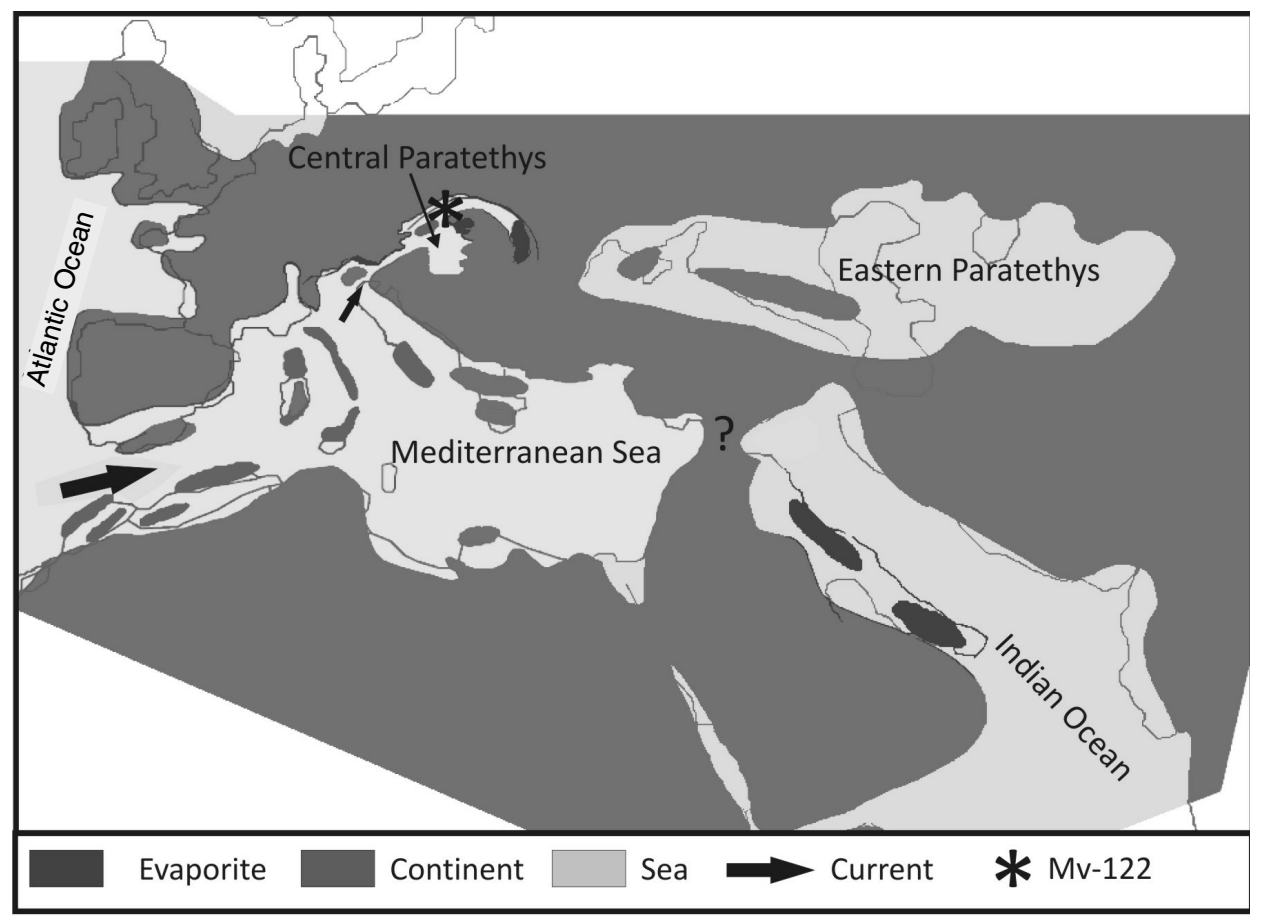

Fig. 1

Paleogeographic map of the Paratethys in the Karpatian (modified after Rögl 1999) 
Meznerics (1951) designated this formation as Garáb Schlier on the basis of its macrofauna. Horváth and Nagymarosy (1978) carried out a detailed stratigraphic study of the schlier on the basis of nannoplankton and foraminifera. Hámor (1985) synthesized the geologic data of this formation in his monograph. He confirmed its Karpatian age and open marine depositional environment. Previous paleontological studies of the Garáb Schlier Formation were focused on the taxonomic description of the fossils, the determination of the stratigraphic position and paleoecological investigations. No detailed statistical analysis of the foraminiferal fauna has been made yet. The aim of this study was a detailed paleoecological investigation in the Mv-122 borehole (Fig. 3), based on qualitative and quantitative analysis of the foraminifera fauna.

\section{Geologic setting}

Mátraverebély is situated about $90 \mathrm{~km}$ northeast of Budapest, in the Salgótarján Basin (Fig. 2). This basin is located in the valley of the Tarján Creek and Zagyva River from Salgótarján to Tar

In the studied area the typical stratigraphic successions of the Hungarian Paleogene Basin is exposed (Báldi 1969, 1980; Báldi and Báldi-Beke 1985; Nagymarosy 2000). Karpatian sedimentation began with the shallow marine, estuarine Egyházasgerge Formation (Hámor 1985). The foraminiferal fauna of the Egyházasgerge Formation is quite rare. The Garáb Schlier Formation, the main focus of this study, overlies and interfingers locally with the Egyházasgerge Formation, indicating a deeper basin. In the upper part of the Karpatian, the Fót Formation (Hámor 1985) was deposited in a shallow-marine reefal environment. The foraminiferal fauna of the Fót Formation is poorly known because of the difficulties of sample processing (Hámor 1985). The Tar Dacite Tuff (Hámor 1985) is commonly regarded as the boundary between Karpatian and Badenian.

The Badenian and younger formations are typical for the North Hungary region. The Lower Badenian is characterized by open marine sediments and volcanites. A shallow marine reef environment is inferred during the Middle Badenian. The faunas of the Sarmatian formations indicate a brackish environment. Brackish marine and lacustrine sediments were also deposited during the Pannonian and Pontian (Hámor 1985, 2001). Piedmont sediments are typical in the area for the Pleistocene and the Holocene (Jámbor 1998).

The latest detailed description of the Garáb Schlier Formation by Hámor has remained unpublished. He defined the Garáb Schlier as cyclically alternating beds of gray, greenish-gray sand, fine-grained micaceous sand, silt, clay and clay marl. He inferred a well-ventilated, offshore, open marine facies, which contains a rich marine fauna. Bioturbation and current marks occasionally appear in it. The Garáb Schlier Formation is situated between the Egyházasgerge and Fót Formations and interfingers with them. The Egyházasgerge Formation differs from the Garáb Schlier Formation in its lower pelite content and its impoverished 


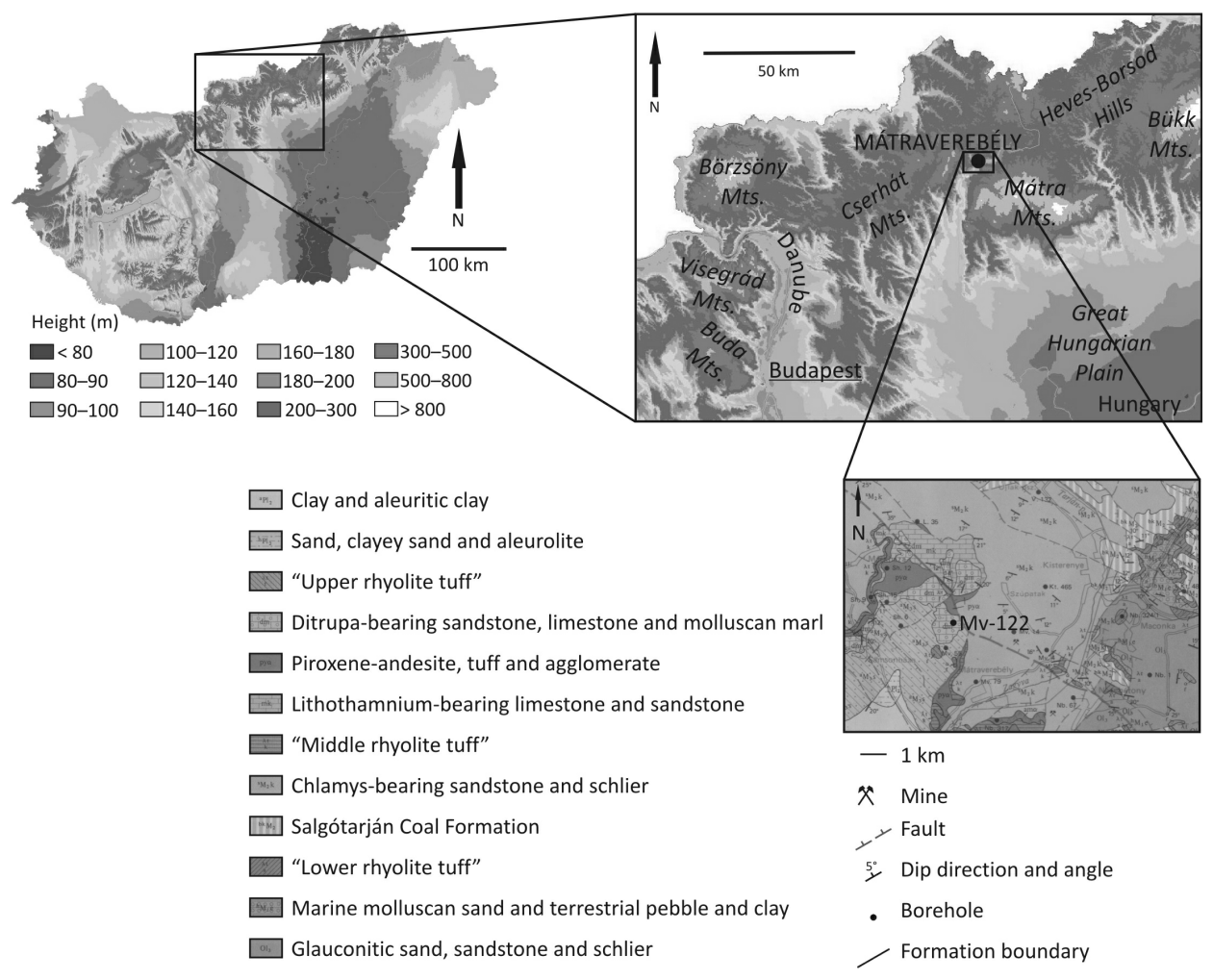

Fig. 2

Location of the Mv-122 borehole (digital elevation base map after MH-TÁTI 1992), and geologic map of the surrounding area (after Hámor 1985)

foraminiferal fauna. On the other hand, the Fót Formation has higher sand and carbonate content than the Garáb Schlier. The maximal water depth was suggested as 100-300 m. The age of the Garáb Schlier is Upper Karpatian (N7-N8 Zone (Blow 1969), NN4 Zone (Martini 1971)) but a Lower Badenian age cannot be excluded (Hámor 1985). The stratotype of this formation is the Garáb (Felsôtold)1 borehole (Hámor 1985). The general stratigraphic thickness of the Garáb Schlier is $200-300 \mathrm{~m}$; the maximum is $600 \mathrm{~m}$, reached in the depocenter of the Zagyva Graben (Hámor, personal communication).

\section{Material and methods}

The Mv-122 borehole was drilled in 1977-1978 by the Nógrád Coal Mines Company; the core logging was carried out by J. Kéri and H. Szemerey. The microfaunal studies were undertaken by B. Kerner and I. Tímár under the supervision of J. Bóna (Hegyi 1979). The sampling from archived material was 
Paleoenvironmental and stratigraphic investigations of the Garáb Schlier Formation (Hungary) 215

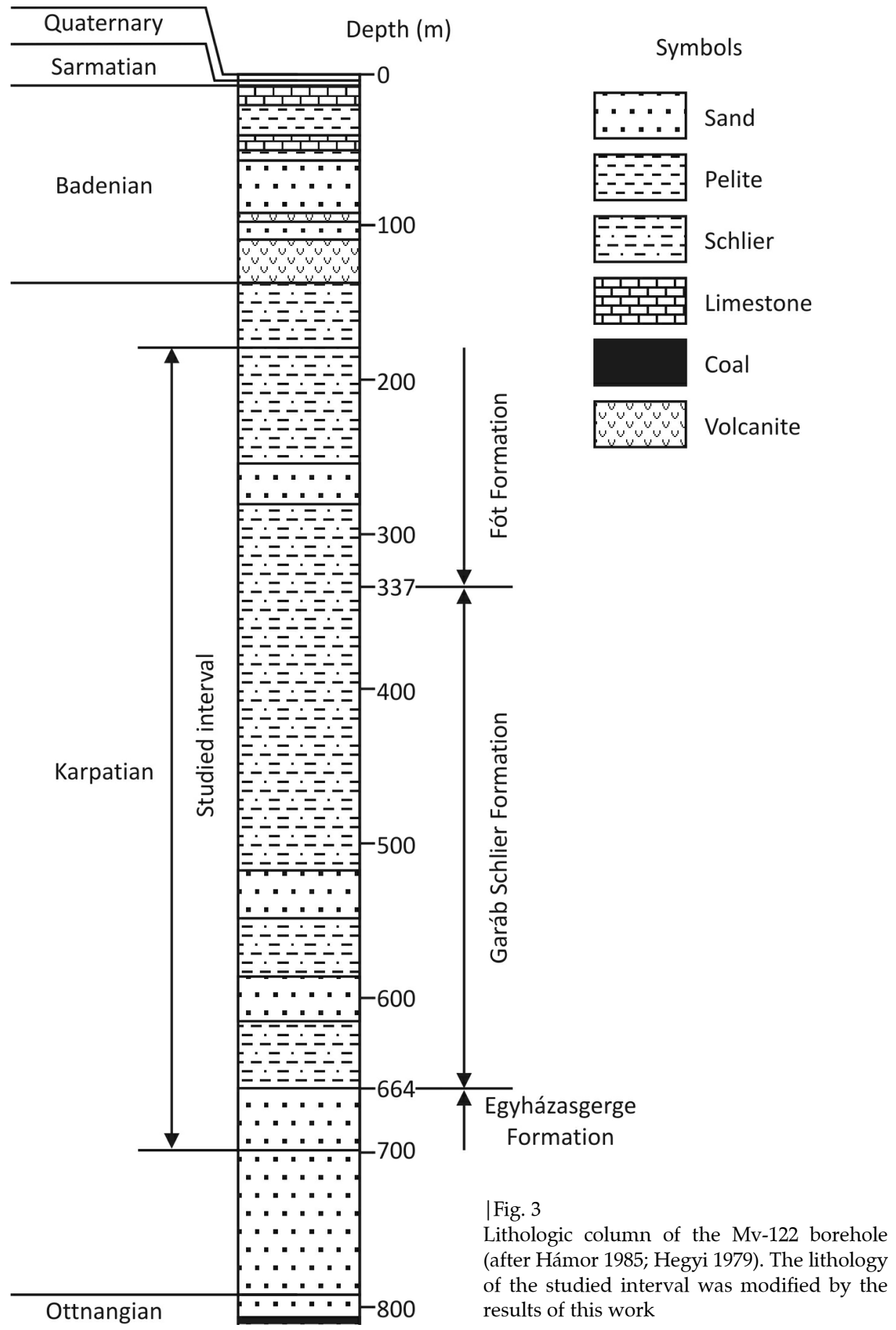


made in 2008 by M. Horváth, Á. Csorba and the present author from the core repository of the Geological Institute of Hungary in Rákóczibánya.

The well-penetrated Sarmatian sediments, mainly limestone and marl, below Quaternary clay. From 7.2 to $146.1 \mathrm{~m}$ Badenian limestone, marl, sandstone and volcanic sediments were encountered, followed by Karpatian tuff mixed with siliciclastic sediments (146.1-177.0 m), clays, clay marl with interbedded sandstone strata and sandstone between 177.0 and $791.3 \mathrm{~m}$. Beneath the Karpatian sediments Ottnangian sandstone, siltstone and coal were encountered. The well reached the depth of 815.4 m (Fig. 3) (Hámor 1985; Hegyi 1979).

Sampling was carried out according to the lithological patterns, with an average sample spacing of $3 \mathrm{~m}$ between 177.0 and $698.0 \mathrm{~m}$. A total of 127 samples were collected, each $500 \mathrm{~g}$ in weight. Of these, 87 samples yielded a sufficient number of foraminifera specimens (at least 300 specimens/sample). The samples were dried, disaggregated in hydrogen peroxide, then washed under running water through a $63 \mu \mathrm{m}$ mesh sieve. Every specimen was tallied and identified at least at generic level following the taxonomy of Loeblich and Tappan (1987), and permanently stored in Franke cells in the Geological Museum of Hungary. A total of 122 taxa were distinguished and entered into a taxonomic abundance/sample data matrix for paleoecological analyses.

The qualitative and quantitative analyses included the following steps:

- Determination of the collected foraminifera.

- Drawing of a "subordo" diagram (Murray 1973, 2006). The basis of this method is the classification of the foraminifera specimens according to their wall structure. The "subordo" diagram is useful for inferring the sedimentary environment.

- Calculation of diversity indices (Fisher's $\alpha$, Shannon-Weaver, Simpson dominance, evenness) with the PAST software (Hammer et al. 2001). The diversity indices reflect the level of environmental stress.

- Calculation of BFOI (Benthic Foraminiferal Oxygen Index), developed by Kaiho (1994 1999), which classifies the calcareous benthic foraminifera by taxonomic and morphologic features into the following groups: oxic (dissolved oxygen: $1.5 \mathrm{ml} / \mathrm{l}$ ), suboxic (dissolved oxygen: $0.3-1.5 \mathrm{ml} / \mathrm{l}$ ), dysoxic (dissolved oxygen: $0.1-0.3 \mathrm{ml} / \mathrm{l})$. The classification is based on the studies of Kaiho (1994 1999), Murray (2006), Vetô et al. (2007) and Pippèrr and Reichenbacher (2010).

- Surface water temperature estimation is based on the works of Hemleben et al. (1989), Spezzaferri and Ćorić (2001), Spezzaferri et al. (2002), and Zágoršek et al. (2008). The planktonic foraminifera are classified as cold, temperate and warm surface water temperature indicators (Zágoršek et al. 2008; Pippèrr and Reichenbacher 2010). The interpretation of the results was made following Spezzaferri (1995) and Spezzaferri and Premoli Silva (1991). Cool surface temperature indicators are Globigerina bulloides, Globigerina dubia, Globigerina lentiana, Globigerina praebulloides, Globigerina tarchanensis, Globigerinoides 
ottnangiensis. Moderate surface temperature indicators are Globigerina concinna, Globoturborotalia woodi, Globigerinella obesa. Warm surface temperature indicators are Globigerinoides bisphaericus, Globigerinoides trilobus.

- Estimation of the depth by planktonic/benthic ratio (PBR), following the slightly different methods of Wright (1977), van Marle (1987) and van der Zwaan et al. (1990). PBRs are expressed using the formula PBR $=P /(P+B) \times 100$. It can be used to estimate the paleobathymetric evolution at a locality. The data were interpreted according to Spezzaferri and Ćorić (2001) and Drinia (2009). These methods are based on recent analogs; thus they include a margin of error. Wright (1977) studied assemblages from slightly restricted environments. The samples of van Marle (1987) stem from the West Papua (formerly Irian Jaya) continental margin. Van der Zwaan et al. (1990) use "stress-taxa" in his method; thus the high number of some "stress taxa" can cause distortion in the inferred depth profile.

\section{Results}

\section{Determination of the foraminifera fauna}

The foraminiferal fauna of the Mv-122 borehole is generally well preserved, abundant and diverse. Benthic foraminifera are represented by 64 genera and 111 species. These taxa belong to the following suborders: Textulariina (16 taxa), Miliolina (7 taxa), Lageniina (24 taxa), Robertinina (1 taxon) and Rotaliina (63 taxa). Planktonic foraminifera are represented by 11 species of 4 genera. The identified taxa are listed in the Appendix. There was no significant loss of foraminiferal tests; therefore these samples are regarded as suitable for paleoecological interpretation.

\section{Ternary plot of foraminifera wall composition ("subordo" diagram)}

A ternary plot of foraminifera wall composition (Murray 1973, 2006) is presented in Fig. 4. Most of the samples cluster near the hyaline vertex, indicating that the fauna lived in a normal salinity sea, and that the hyaline-walled taxa were predominant. Calcareous specimens are represented by 70 to $100 \%$ of all benthic foraminifera with the exception only of 7 samples.

\section{Diversity indices}

Figure 5 shows the trends in the diversity indices along the section. Lowdiversity associations are dominated by a few species, indicating a stressed environment. Relatively diverse fauna occur in a more stable, normal marine environment. The mean values of these indices result in different environments during the Karpatian. The spread of the values of Fisher's $\alpha$ index is relatively high (1.06-30.70), but these scattered values indicate different inferred environments. This feature (the scatter of values) is characteristic in the case of 


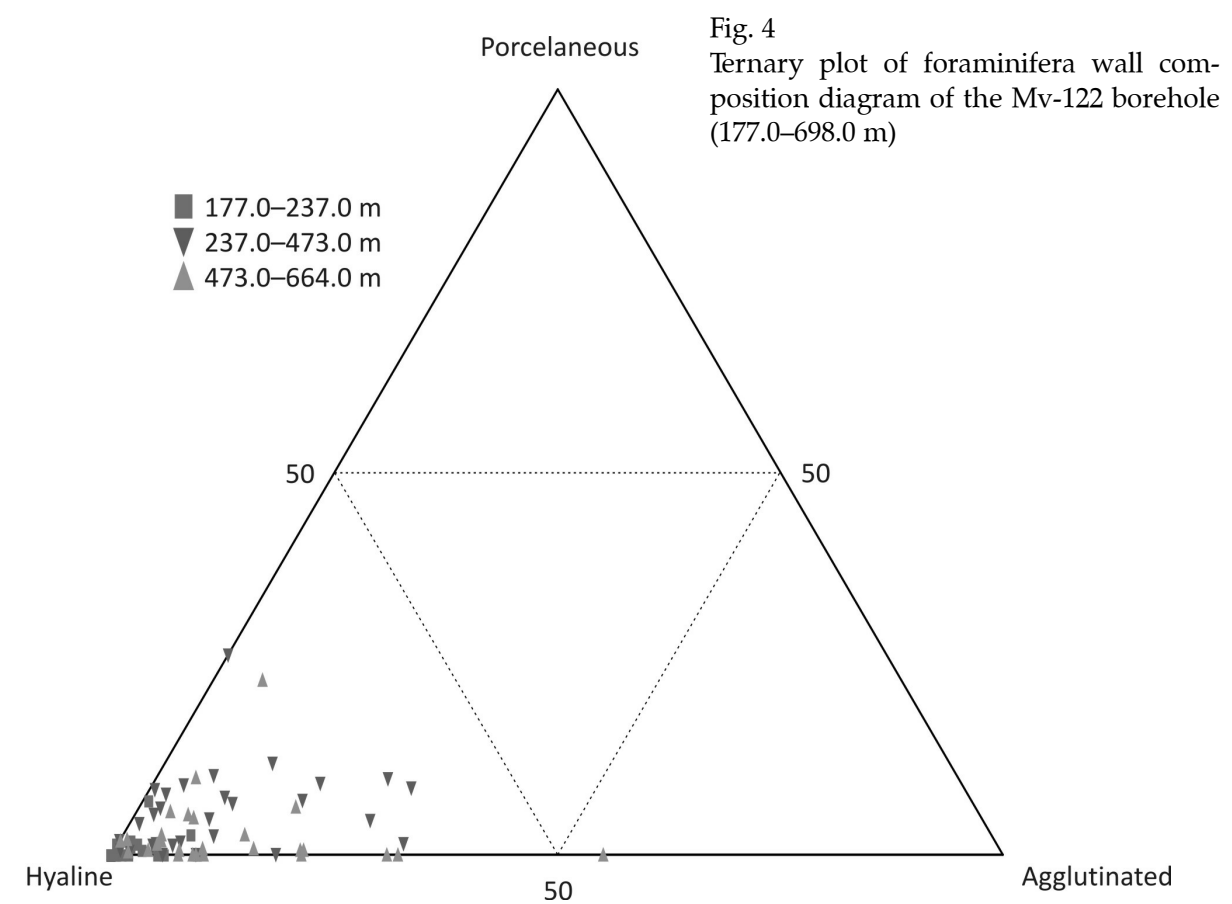

the Shannon-Weaver index, the Simpson dominance and evenness as well. The maximum of the Shannon-Weaver index is 3.21; the minimum is 0.31 . The values of the Simpson dominance vary between 0.12 and 0.95 . The evenness ranges from 0.15 to 0.92 .

\section{Benthic Foraminiferal Oxygen Index}

The application of the BFOI method (Kaiho 1994, 1999) allows the reconstruction of the dissolved oxygen level of the ancient bottom water. The obtained values vary between 0 and 98.41 (Fig. 5). This means that the bottom water was largely oxic but that throughout the deposition of the Garáb Schlier the level of oxygenation was variable. Only 10 samples indicate low oxic conditions $(\mathrm{BFOI}<15)$; these occur in the $177.0-258.0 \mathrm{~m}$ interval. High oxygen levels (BFOI>50) were determined for the $664.0-519.0 \mathrm{~m}, 371.0-432.0 \mathrm{~m}$, and 262.0-352.0 m intervals. Moderately oxic conditions (BFOI: 15-50) can be detected from $432.0-519.0 \mathrm{~m}$ and $352.0-371.0 \mathrm{~m}$. Low oxic conditions are inferred from the samples between 177.0 and $262.0 \mathrm{~m}$. 
Paleoenvironmental and stratigraphic investigations of the Garáb Schlier Formation (Hungary) 219

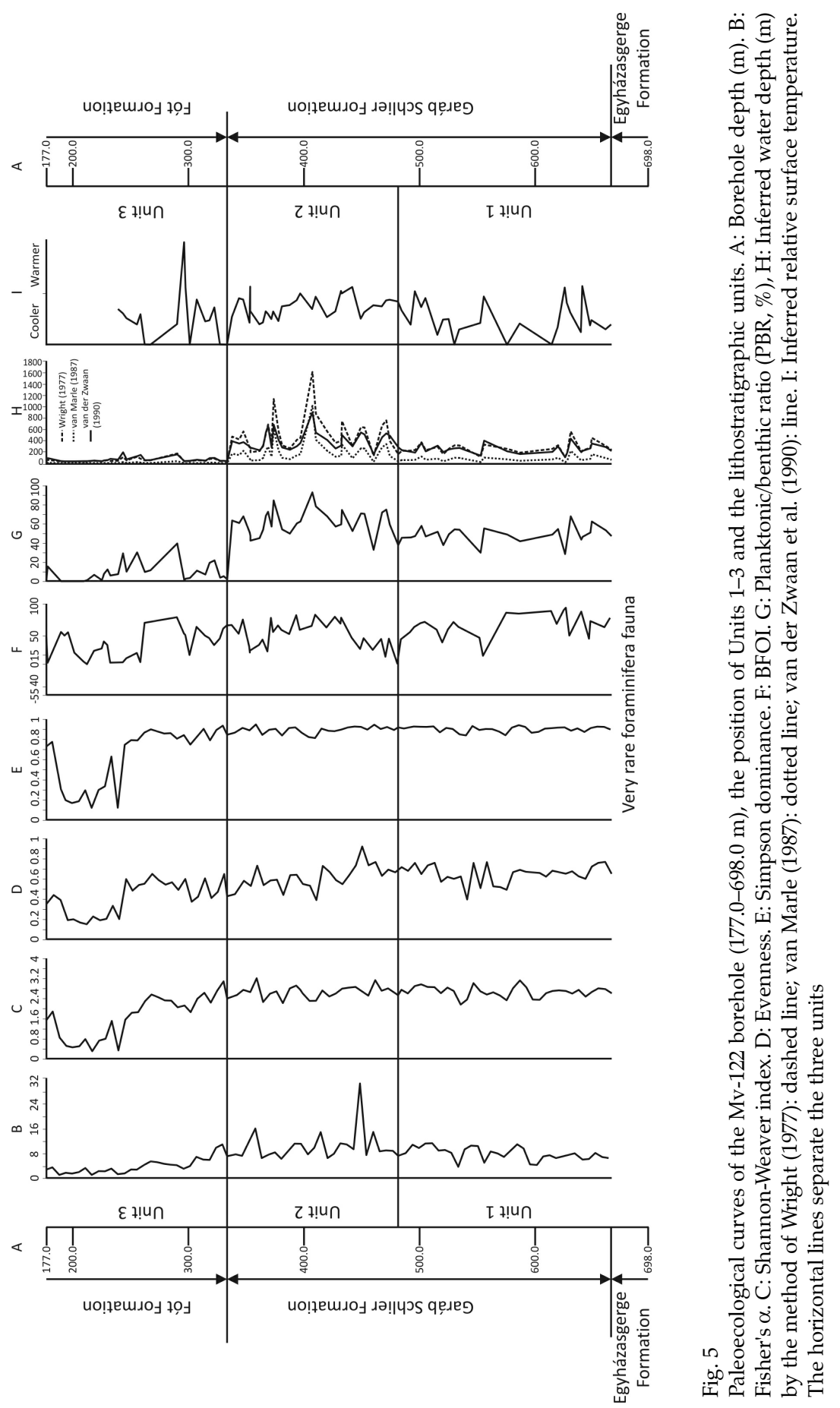

Central European Geology 54, 2011 


\section{Surface water temperature}

Cold water indicator planktonic species are dominant in the studied section. Only three samples contain warm water indicator taxa but the maximum proportion of these is only $16 \%$. Moderate temperature indicator taxa represent $20-40 \%$ in general, but 8 samples contain more than $50 \%$ of them. Cool or temperate-cool surface water can be inferred by this method (Fig. 5).

\section{Depth estimation}

Changes in PBR and the derived depth curves using the estimation method of three different authors are shown in Fig. 5. In the discussion of the following text the water depths are calculated using the method of van der Zwaan et al. (1990). This method considers the amount of inbenthic foraminifera and was tested in the Adriatic Sea which has geologic and ecological features similar to the Paratethys. Between 473.0 and $664.0 \mathrm{~m}$ the PBR fluctuates from $40 \%$ to $60 \%$, and the inferred water depth varies between 210 and $310 \mathrm{~m}$. The maximum in PBR were detected in the 337.0-473.0 m interval. Here the estimated water depth is generally greater than $400 \mathrm{~m}$. From $177.0 \mathrm{~m}$ to $337.0 \mathrm{~m}$ the water depth decreases drastically. Above $330 \mathrm{~m}$ the PBR is usually less than $20 \%$. Therefore the estimated water depth is less than $100 \mathrm{~m}$ for this part of the section.

\section{Biostratigraphy}

Benthic stratigraphy

Although benthic foraminifera are less useful for biostratigraphy than the planktonic forms, nevertheless the Miocene sediments of the Paratethys can be dated by benthic taxa as well, at least at a basinal scale. The base of the Karpatian was defined by the first occurrence of Uvigerina graciliformis (Plate 1.8) (Papp et al. 1971). Both Reticulophragmium karpaticum (Plate 1.1) (which is restricted to the Karpatian (Cicha et al. 1998)) and Uvigerina graciliformis first occur in the sample from $664.0 \mathrm{~m}$. The highest occurrence of Pappina primiformis (Plate 1.7), Elphidium ortenburgense (Plate 1.11) and E. subtypicum (Plate 1.12) is recorded at $177.0 \mathrm{~m}$; the last occurrence of these species elsewhere in the Paratethys is known from within the Karpatian (Cicha et al. 1998). Based on these constraints the age of our samples is Karpatian. The total range of these species in the Mv- 122 borehole is unknown.

\section{Planktonic stratigraphy}

The abundance of the planktonic foraminifera shows significant variability. Overall planktonic forms occur abundantly except for the $177.0-337.0 \mathrm{~m}$ interval. The composition of the planktonic fauna is typical for the Karpatian. Globigerina 


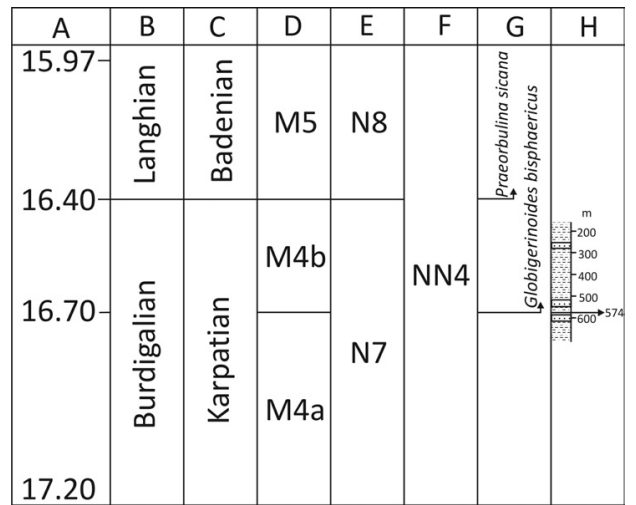

Fig. 6

Stratigraphic position of the studied section. A: Million years (Corić et al. 2009). B: Mediterranean age. C: Central Paratethys age. D: Planktonic Foraminiferal Zonation (Berggren et al. 1995). E: Planktonic Foraminiferal Zonation (Blow 1969). F: Nannoplankton Zonation (Martini 1971). G: First Occurrence Datum of diagnostic taxa (Berggren et al. 1995). H: Position of the studied interval of Mv-122

bulloides (Plate 1.3) and Globigerina concinna (Plate 1.4) had their first occurrence at the base of the Karpatian (Cicha et al. 1998). The last occurrence of Globigerina dubia (Plate 1.5) and Globoturborotalia ottnangiensis (Plate 1.6) is recorded in the Karpatian (Cicha et al. 1998). These species are common in the studied section of the Mv-122 borehole. The upper boundary of the Karpatian may be defined as the last occurrence of Globigerina ottnangiensis, but one must consider that the $177.0-337.0 \mathrm{~m}$ interval is relatively rare in planktonic foraminifera. The most important planktonic biostratigraphic event in the Karpatian is the first occurrence of Globigerinoides bisphaericus, which marks the base of M4b Planktonic Foraminifera Zone (16.7 Ma), in the latest Burdigalian (Berggren et al. 1995). This species occurs in the samples at $230.0,554.0$ and $574.0 \mathrm{~m}$; therefore the base of the M4b Planktonic Foraminifera Zone in the Mv-122 borehole is at 574.0 $\mathrm{m}$. Ćorić et al. (2009) defined the base of the Badenian as the first occurrence of Praeorbulina sicana (16.303 Ma), which is not represented in this samples.

On the basis of the presence of the Globigerinoides bisphaericus Datum and the absence of the Praeorbulina sicana Datum the stratigraphic position of the studied section is correlated with the M4b Planktonic Foraminifera Zone (Fig. 6).

\section{Discussion}

Foraminiferal assemblages are suitable for paleoecological analyses because of their taxonomic richness and abundance, as well as widespread occurrence in different geographic areas and environments. Paleoecological inferences on foraminifera may be based on recent analogies. Their occurrence and distribution are influenced by many abiotic and biotic ecological factors. Oxygenation, temperature, depth, salinity and other environmental parameters can be estimated by the analysis of the foraminifera assemblage.

In the studied section of the Garáb Schlier Formation in borehole Mv-122, three different environments could be distinguished by application of the paleoecological methods discussed above. 


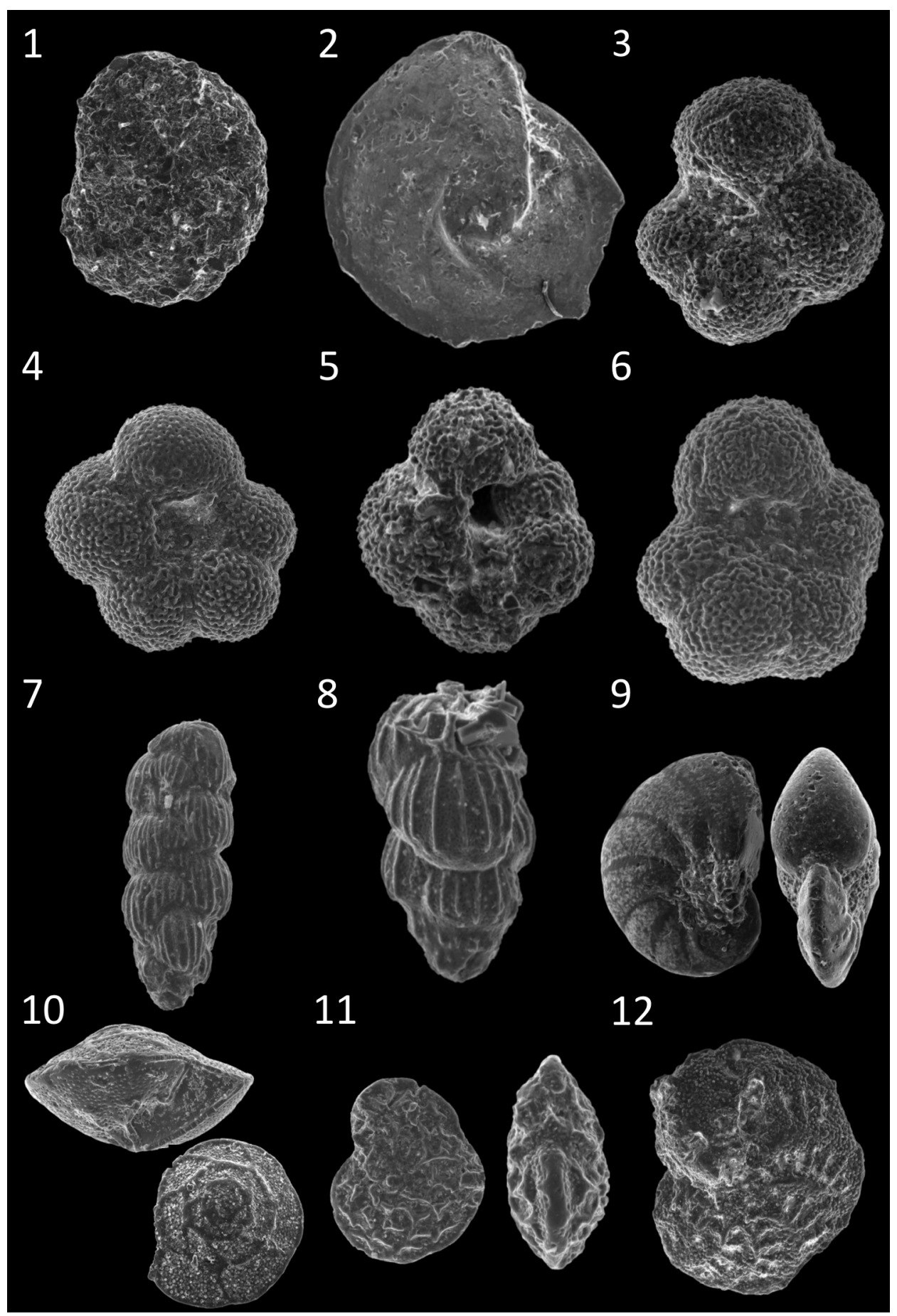

Central European Geology 54, 2011 
Unit 1, 698.0-473.0 m: outer shelf - upper bathyal transitional environment

In the lowest part of the studied section $(664.0-698.0 \mathrm{~m})$ the sediments are sandier than upsection and foraminifera are very rare.

From 664.0 to $473.0 \mathrm{~m}$ the diversity measured by Fisher's $\alpha$ index varies around 7, values of the Shannon-Weaver index and Simpson dominance show little change. The evenness is less variable than in the other parts of the section (Table 1). The BFOI fluctuates significantly but it indicates a well-oxygenated environment. Both the BFOI and the inferred water depth decrease slightly upsection. The higher value of the average water depth is explained by the proximity of the upper bathyal zone and the open connection with pelagic water masses.

The most dominant planktonic forms are the following: Globigerina bulloides, Globoturborotalia ottnangiensis and Globigerinella obesa. The most common benthic taxa are Bolivina hebes, Bulimina elongata, Pappina parkeri, Cibicidoides lopjanicus, Heterolepa dutemplei (Plate 1.10), Hanzawaia boueana, Melonis pompilioides and Pullenia bulloides.

The sediments of these samples were deposited in a well-oxygenated, normal marine, cool, outer shelf environment in proximity to the upper bathyal zone and connection with the open sea. The Western European open marine outer shelves provide a good modern analog of this environment (Murray 1991).

This phase may be equated with the sublittoral and open marine facies of Karpatian mesocycle 2, as described by Hámor 1985 (Fig. 7).

\section{Unit 2, 473.0-337.0 m: upper bathyal environment}

Within this unit, the Fisher's $\alpha$ and Shannon-Weaver indices, the Simpson dominance and the evenness show relatively little change; the deviations of these indices are nevertheless higher than in the previous interval (Table 1). This unit can be divided into two parts. Between 473.0 and $441.0 \mathrm{~m}$ the inferred water depth was upper bathyal, not exceeding $600 \mathrm{~m}$. There is high measured fluctuation in the depth profile which caused by changes in ecological factors or

\section{$\leftarrow$ Plate 1}

1. Reticulophragmium karpaticum Cicha and Zapletalová, plan view, $\times 72$

2. Lenticulina inornata (d'Orbigny), plan view, $\times 51$

3. Globigerina bulloides d'Orbigny, umbilical view, $\times 104$

4. Globigerina concinna Reuss, umbilical view, $\times 168$

5. Globigerina dubia Egger, umbilical view, $\times 156$

6. Globoturborotalia ottnangiensis Rögl, umbilical view, $\times 133$

7. Pappina primiformis (Papp and Turnovsky), plan view, $\times 66$

8. Uvigerina graciliformis Papp and Turnovsky, plan view, $\times 80$

9. Nonion commune (d'Orbigny), plan and apertural view, $\times 55$ and $\times 58$

10. Heterolepa dutemplei d'Orbigny, apertural and dorsal view, $\times 43$ and $\times 57$

11. Elphidium ortenburgense (Egger), plan and apertural view, $\times 65$ and $\times 52$

12. Elphidium subtypicum Papp, plan view, $\times 76$ 


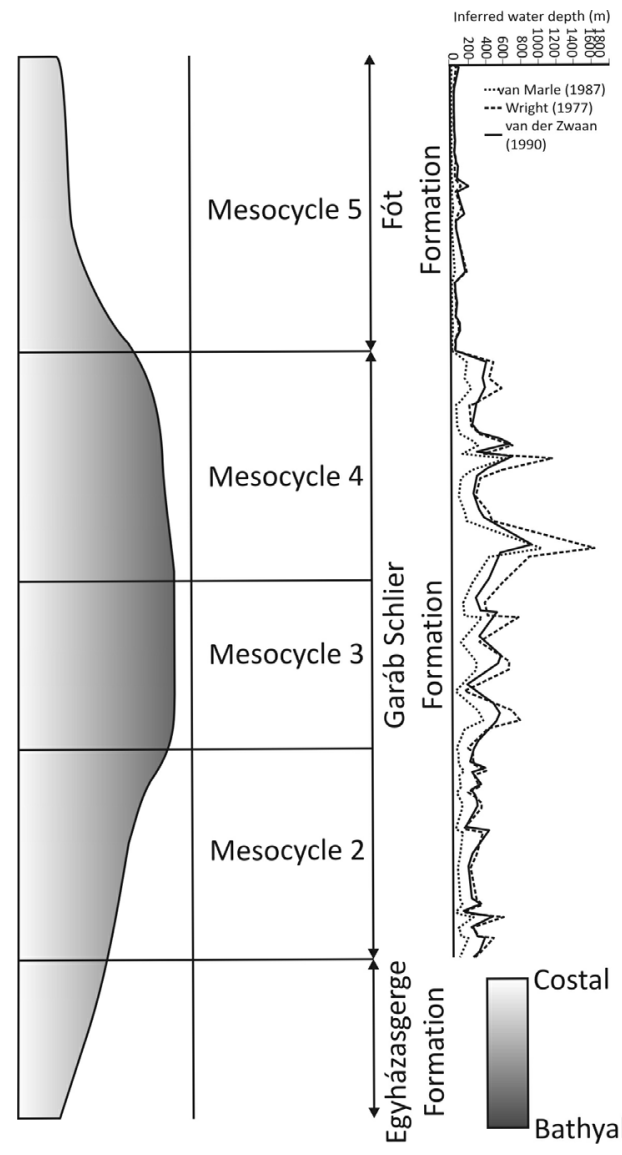

Fig. 7

Depth profile in the Mv-122 borehole and suggested correlation with the mesocycles according to the terminology of Hámor (1985) connections with other marine areas, not in the water depth. The BFOI indicates moderate or low oxic conditions. The highest PBRs (and greatest water depths) were observed from 441.0 to $337.0 \mathrm{~m}$, indicating that occasionally middle bathyal depth was reached. The BFOI in this part is higher than anywhere else in the entire studied section. The dominant planktonic foraminifera taxa are Globigerina bulloides, G. concinna, G. praebulloides, Globoturborotalia ottnangiensis and Globigerinella obesa. The most abundant benthic forms (which represent more than $10 \%$ of the community in at least one of the samples) are Spirorutilus carinatus, Bolivina dilatata dilatata, Bulimina elongata, B. subulata, Globobulimina pupoides, Praeglobobulimina pyrula, Pappina breviformis and Heterolepa dutemplei. There are several taxa, such as Reticulophragmium karpaticum, Semivulvulina pectinata, Sigmoilopsis celata, Plectofrondicularia div. sp., Lenticulina div. sp. (Plate 1.2), Fursenkoina acuta, Cibicidoides div. sp., Gyroidina neosoldanii and Hanzawaia boueana, that are not abundant but nevertheless represented in nearly every sample.

A deep, normal salinity, cool marine environment without permanent currents is inferred. The Bay of Biscay and the offshore Portugal shelf-slope environment are the most analogous modern areas described by Murray $(1991,2006)$.

The 473.0-337.0 m interval is identified with mesocycles 3 and 4 of Hámor (1985), defined as open marine facies (Fig. 7).

\section{Unit 3, 337.0-177.0 m: inner shelf environment}

In this interval, the diversity indices show a pronounced decrease; only a slight rebound toward higher values is observed at the top of the section (Table 1). On the basis of the wall structure distribution of the foraminifera, an open marine 
Table 1

Summary of quantitative paleoecological parameters of the foraminifera assemblages and inferred depth and oxygenation levels for the three distinguished units

\begin{tabular}{|l|r|r|r|r|r|r|r|r|r|r|r|r|}
\hline & \multicolumn{4}{|c|}{$177.0-337.0 \mathrm{~m}$} & \multicolumn{4}{|c|}{$337.0-473.0 \mathrm{~m}$} & \multicolumn{3}{|c|}{$473.0-698.0 \mathrm{~m}$} \\
\cline { 2 - 14 } & $\max$ & $\min$ & average & deviation & $\max$ & $\min$ & average & deviation & $\max$ & $\min$ & average & deviation \\
\hline Fisher's $\alpha$ & 10.9 & 1.06 & 4.2 & 2.56 & 30.70 & 6.28 & 10.4 & 4.55 & 11.00 & 3.68 & 7.54 & 1.92 \\
\hline $\begin{array}{l}\text { Shannon- } \\
\text { Weaver index }\end{array}$ & 3.09 & 0.31 & 1.76 & 0.84 & 3.21 & 2.22 & 2.70 & 0.23 & 3.12 & 2.17 & 2.65 & 0.22 \\
\hline $\begin{array}{l}\text { Simpson } \\
\text { dominance }\end{array}$ & 0.94 & 0.12 & 0.66 & 0.29 & 0.95 & 0.81 & 0.90 & 0.03 & 0.94 & 0.84 & 0.90 & 0.03 \\
\hline Evenness & 0.65 & 0.15 & 0.42 & 0.16 & 0.92 & 0.39 & 0.64 & 0.11 & 0.77 & 0.39 & 0.64 & 0.09 \\
\hline PBR & 39.67 & 0.00 & 9.05 & 7.75 & 93.00 & 33.00 & 62.57 & 10.17 & 68.00 & 28.67 & 48.18 & 6.49 \\
\hline $\begin{array}{l}\text { Inferred water } \\
\text { depth }\end{array}$ & 195.53 & 36.13 & 65.93 & 29.64 & 900.54 & 164.87 & 405.30 & 127.33 & 437.35 & 107.03 & 247.70 & 61.79 \\
\hline BFOI & 94.68 & 0.00 & 37.62 & 23.30 & 86.21 & 13.04 & 52.03 & 18.65 & 98.41 & 1.00 & 65.14 & 18.34 \\
\hline
\end{tabular}

environment is inferred. The open marine connection is also reflected in the occasional larger number of planktonic forms. The low values of Simpson dominance are caused by the abundance of Nonion commune (Plate 1.9). The calculated water depth is commonly less than $60 \mathrm{~m}$; the greater depth values are accounted for by higher PBR, which in turn may be related to the connection with the open marine environment. The BFOI indicates a well-oxygenated environment, although there are some samples where the oxygenation index is lower. In the low BFOI communities, which suggest oxygen-depleted conditions, the most common taxa are Bolivina dilatata dilatata, B. dilatata brevis, B. simplex, Bulimina elongata, B. subulata, Pappina breviformis and Fursenkoina acuta.

A shallow marine, normal salinity environment is inferred, with open marine connections. The influence of a river from the nearby continental area (Hámor 1985) can explain the lower BFOI by the transport of a greater amount of organic material. This environment may be analogous to the Western Mediterranean deltas (e.g. Rhône, Ebro, Banyulus-sur-Mer) described by Murray $(1991,2006)$.

The original definition of the Garáb Schlier Formation (Hámor 1985) interprets it as an open marine, offshore formation. On the basis of this definition, this part of the section (337.0-177.0 m) does not belong to the Garáb Schlier Formation. It is best regarded as sublittoral and mainly littoral sediments that belong to the overlying Fót Formation and represent mesocycle 5 of Hámor (1985), but in this borehole a sudden change can be observed, while Hámor (1985) describes a continuous transition from bathyal to shallow marine environments (Fig. 7).

\section{Conclusions}

Taxonomic, paleoecological and biostratigraphic analyses of the foraminifera fauna of the Garáb Schlier and Fót Formations were carried out, based on the detailed study of the Mv-122 borehole. Of the 127 samples collected, 87 samples 
yielded a suitable number of specimens for the quantitative foraminifera analysis. A total of 26,100 specimens of 122 foraminifera taxa were determined, counted and used for quantitative paleoecological analyses.

Diversity indices, paleobathymetric and temperature estimation as well as BFOI were used for the paleoecological investigations. The studied fauna was compared to recent assemblages.

The main results are as follows:

1. Most faunal assemblages suggest normal salinity, cool, marine environments with well-oxygenated bottom water (except some sample from Unit 3).

2. Three depositional environmental units are distinguished on the basis of paleoecological data. The foraminiferal assemblages are characteristic for upper bathyal, outer shelf and inner shelf environments, respectively. The composition of the assemblages compares well with the modern faunas of the Western European Atlantic and the Western Mediterranean areas.

3. The upper part of the studied section does not belong to the Garáb Schlier Formation. Its foraminiferal fauna favors an assignment to the Fót Formation, which was deposited in a shallower, sublittoral setting.

4. The transition from Garáb Schlier Formation to Fót Formation may not be as gradual, as previously suggested on the basis of the foraminifera fauna.

5. Foraminifera biostratigraphy suggests the presence of the M4b Planktonic Foraminiferal Zone. Thus the studied section belongs to Karpatian.

6. The $337.0-664.0 \mathrm{~m}$ interval of the $\mathrm{Mv}-122$ borehole is proposed as a hypostratotype of the Garáb Schlier Formation.

\section{Acknowledgements}

I express my grateful thanks to my supervisor Mária Horváth for her helpful advice. I am indebted to András Nagymarosy and Éva Szegő for their valuable comments and to József Pálfy for his suggestions to improve an earlier draft of the manuscript. I am grateful to László Kordos for permitting the sampling of the core of the Mv-122 borehole. Thanks are due to Ádám Csorba and Attila Virág for their useful recommendations. This work was supported by MOL Hungarian Oil and Gas Company.

\section{References}

Báldi, T. 1969: On the Oligocene and Miocene stages of the Central Paratethys and on the formations of the Egerian in Hungary. - Annales Universitatis Scientiarum Budapestinensis de Rolando Eötvös Nominatae Sectio Geologica, 12, pp. 19-28.

Báldi, T. 1980: A korai Paratethys története. (The early History of Paratethys) - Földtani Közlöny, 110/3-4, pp. 456-472.

Báldi, T. 1986: Mid-Tertiary Stratigraphy and Paleogeographic Evolution of Hungary. - Akadémiai Kiadó, Budapest, 201 p.

Báldi, T., M. Báldi-Beke 1985: The evolution of the Hungarian Paleogene Basin. - Acta Geologica Hungarica, $18 / 1-2$, pp. 5-28. 
Berggren, W.A., D.V. Kent, C.C. Swisher III, M.P. Aubry 1995: A revised Cenozoic geochronology and chronostratigraphy. - In: Berggren, W.A., J. Hardenbol, P.A. Scholle (Eds): 1995: Geochronology, Time Scales, and Global Stratigraphic Correlation. - Special Publication of Society for Sedimentary Geology, 54, Tulsa, pp. 129-212.

Blow, W.H. 1969: Late Middle Eocene to Recent planktonic foraminiferal biostratigraphy. - In: Bronnimann, P., H.H. Renz (Eds): Proceedings of the First International Conference on Planktonic Microfossils, Geneva, Brill, Leiden, 1, pp. 199-421.

Cicha, I., F. Rögl, Ch. Rupp, J. Ctyroká 1998: Oligocene-Miocene foraminifera of the Central Paratethys. - Verlag Waldemar Kramer, Frankfurt am Main, 325 p.

Ćorić, S., D. Pavelić, F. Rögl, O. Mandić, S. Vrabac, R. Avanić, L. Jerković, A. Vranjković 2009: Revised Middle Miocene datum for initial marine flooding of North Croatian Basins (Pannonian Basin System, Central Paratethys). - Geologica Croatia, 62/1, pp. 31-43.

Csepreghyné Meznerics, I. 1951: A salgótarjánvidéki slír és pectenes homokkő faunája. (La faune du schlier et du grès à Pecten des environs de Salgótarján) - Földtani Közlöny, 81/4, pp. 303-319.

Drinia, H. 2009: Palaeoenvironmental reconstruction of the Oligocene Afales Basin, Ithaki island, western Greece. - Central European Journal of Geosciences, 1/1, pp. 1-18.

Hammer, Ø., D.A.T. Harper, P.D. Ryan 2001: PAST: Paleontological Statistics Software Package for Education and Data Analysis. Palaeontologia Electronica 4/1, 9 p. http://palaeoelectronica.org/2001_1/past/issue1_01.htm

Hámor, G. 1985: A Nógrád-Cserhát kutatási terület földtani viszonyai. (Geology of the Nógrád-Cserhát Area) - Geologica Hungarica Series Geologia, 22, pp. 80-94, 180-188.

Hámor, G. 2001: Magyarázó a Kárpát-medence miocén ôsföldrajzi és fácies térképéhez 1:3000000. (Miocene palaeogeography of the Carpathian Basin. Explanatory notes to Miocene palaeogeographic maps of the Carpathian Basin, 1:3000 000) - A Magyar Állami Földtani Intézet Térképmagyarázói, Magyar Állami Földtani Intézet, Budapest, 67 p.

Hámor, G. 2007: Results of a statistical evaluation of the Neogene in Hungary. - Central European Geology, 50/2, pp. 101-182.

Hantken, M. 1878: A magyar korona országainak széntelepei és szénbányászata. (Die Kohlenflötze und der Kohlenbergbau in den Lädern der Ungarischen Krone) - A Margyar Királyi Földtani Intézet Különleges Kiadványa, Budapest, 139 p.

Hegyi, J. (Ed.) 1979: A Mátraverebély-122 fúrás anyagvizsgálati eredménye. [The results of the geological analyses of Mátraverebély-122 borehole] - Manuscript, Magyar Bányászati és Földtani Hivatal [Hungarian Office for Mining and Geology], Budapest.

Hemleben, Ch., M. Spindler, O.R. Anderson 1989: Modern Planktonic Foraminifera. - SpringerVerlag New York Incorporated, New York, pp. 220-257.

Horváth, M., A. Nagymarosy 1978: On the age of the Rzehakia-beds and Garáb Schlier based on Foraminifera and Nannoplankton investigations. - Annales Universitatis Scientiarum Budapestinensis de Rolando Eötvös Nominatae Sectio Geologica, 20, pp. 3-21.

Jámbor, Á. 1998: A magyarországi kvarter (negyedidőszaki) képződmények rétegtanának áttekintése. [The stratigraphy of the Hungarian Quaternary formations] - In: Bérczi, I., Á. Jámbor (Eds): 1998: Magyarország geológiai képződményeinek rétegtana. (Stratigraphy of geological formations of Hungary) - A MOL Rt. és a MÁFI kiadványa, Budapest, pp. 495-517.

Kaiho, K. 1994: Benthic foraminiferal dissolved oxygen index and dissolved oxygen levels in the modern ocean. - Geology, 22/8, pp. 719-722.

Kaiho, K. 1999: Effect of organic carbon flux and dissolved oxygen on the benthic foraminiferal oxygen index (BFOI). - Marine Micropaleontology, 37, pp. 67-76.

Kováč, M., A.S. Andreyeva-Grigorovich, R. Brzobohatý, L. Fodor, M. Harzhauzer, N. Oszczypko, D. Pavelić, B. Saftić, L. Silva, Z. Stárník 2003: Karpatian Paleogeography, Tectonics and Eustatic Changes. - In: Brzobohatý, R., I. Cicha, M. Kováč, F. Rögl (Eds): The Karpatian. A Lower Miocene Stage of Central Paratethys. - Masaryk University, Brno, pp. 49-72.

Loeblich, A.R., H. Tappan 1987: Foraminiferal Genera and their Classification. - Van Nostrand Rienhold Company, New York, 970 p. 
Martini, E. 1971: Standard Tertiary and Quaternary calcareous nannoplankton zonation. - In: Farinacci, A. (Ed.): Proceedings of the Second Planktonic Conference, Roma, 1970, Tecnoscienza, pp. 739-785.

Magyar Honvédség Tóth Ágoston Térképészeti Intézete [MH-TÁTI, Hungarian Army, Ágoston Tóth Institute of Cartography] 1992: DDM-10. - A Magyar Köztársaság 10 méter vízszintes felbontású digitális domborzati modellje. [DEM-10. - $10 \mathrm{~m}$ horizontal resolution digital elevation model of the Republic of Hungary]

Murray, J.W. 1973: Distribution and Ecology of Living Benthic Foraminiferids. - Heinemann Educational Books, London, $271 \mathrm{p}$.

Murray, J.W. 1991: Ecology and Paleoecology of Benthic Foraminifera. - Longman Scientific and Technical, Harlow, 397 p.

Murray, J.W. 2006: Ecology and Applications of Benthic Foraminifera. - Cambridge University Press, Cambridge, $426 \mathrm{p}$.

Nagymarosy, A. 2000: Paleogén rétegtan és ôsföldrajz. (Paleogene stratigraphy and palaeogeography) - In: Karátson, D. (Ed.): Magyarország földje. Kitekintés a Kárpát-medence egészére. (The land that is Hungary) - Pannon Enciklopédia, Kertek 2000 Könyvkiadó, Budapest, pp. 108-112.

Noszky, J., sen. 1912: A Salgótarjáni szénterület földtani viszonyai. [Geological setting of the coal bearing strata in the surrounding area of Salgótarján] - Koch emlékkönyv, pp. 67-90.

Noszky, J., sen. 1914: A Cserhát középső részének földtani viszonyai. [Geological setting of the middle part of Cserhát Mountains] - A Magyar Királyi Földtani Intézet évi jelentése 1913-ról, pp. 305-325.

Noszky, J., sen. 1929: A Magyar Középhegység Schlier rétegei. Adalékok a Schlier kérdés megítéléséhez. [The schlier strata of the Hungarian Mountains. Commentary to the adjucation of the Schlier problem] - Debreceni Tisza István Tudományos Társaság II. (orvostermészettudományi) osztályának munkái. 3/2, pp. 81-128.

Papp, A., F.F. Steininger, F. Rögl 1971: Bericht über die Ergebnisse der 3. Sitzung der Arbeitsgruppe Paratethys des Committee Mediterranean Neogene Stratigraphy 1970 in Wien. Verhandlungen der Geologischen Bundesanstalt 1971, pp. 59-62.

Pippèrr, M., B. Reichenbacher 2010: Foraminifera from the borehole Altdorf (SE Germany): Proxies for Ottnangian (early Miocene) palaeoenvironments of the Central Paratethys. Palaeogeography, Palaeoclimatology, Palaeoecology 289, pp. 62-80.

Rögl, F. 1999: Mediterranean and Paratethys. Facts and hypothesis of an Oligocene to Miocene paleogeography (short overview). - Geologica Carpathica 50/4, pp. 339-349.

Spezzaferri, S. 1995: Planktonic foraminiferal paleoclimatic implications across the Oligocene-Miocene transition in the oceanic record (Atlantic, Indian and South Pacific). Palaeogeography, Palaeoclimatology, Palaeoecology, 114/1, pp. 43-74.

Spezzaferri, S., S. Ćorić 2001: Ecology of Karpatian (Early Miocene) foraminifers and calcareous nannoplankton from Laa An Der Thaya, Lower Austria: a statistical approach. - Geologica Carpathica, 52/6, pp. 361-374.

Spezzaferri, S., S. Ćorić, J. Hohenegger, F. Rögl 2002: Basin-scale paleobiogeography and paleoecology: an example from Karpatian (Latest Burdigalian) benthic and planktonic foraminifera and calcareous nannofossils from the Central Paratethys. - Geobios 35 (Mémoire spécial n²4), pp. 241-256.

Spezzaferri, S., I. Premoli Silva 1991: Oligocene planktonic foraminiferal biostratigraphy and paleoclimatic interpretation from Hole 538A, DSDP Leg 77, Gulf of Mexico. - Palaeogeography, Palaeoclimatology, Palaeoecology, 83/1-3, pp. 217-263.

van der Zwaan, G.J., FJ. Jorissen, H.C. de Stigter 1990: The depth dependency of planktonic/benthic foraminiferal ratios: constraints and applications. - Marine Geology, 95, pp. 1-16.

van Marle, L.J. 1987: Bathymetric distribution of benthic Foraminifera on the Australian-Irian Jaya continental margin, Eastern Indonesia. - Marine Micropaleontology, 13, pp. 97-152. 
Vetô, I., P. Ozsvárt, I. Futó, M. Hetényi 2007: Extension of carbon flux estimation to oxic sediments based on sulphur geochemistry and analysis of benthic foraminiferal assemblages: A case history from the Eocene of Hungary. - Palaeogeography, Palaeoclimatology, Palaeoecology, 248/1-2, pp. 119-144.

Wright, R.G. 1977: Planktonic-benthic ratio in Foraminifera as paleobathymetric tool. Quantitative evaluation. - Annales American Association of Petroleum Geologists Society, 65 p.

Zágoršek, K., K. Holcová, T. Tŕasoň. 2008: Bryozoan event from Middle Miocene (Early Badenian) lower neritic sediments from the locality Kralice nad Oslavou (Central Paratethys, Moravian part of the Carpathian Foredeep). - International Journal of Earth Sciences, 97/4, pp. 835-850

\section{Appendix}

List of foraminifera from the Mv-122 borehole (between 177.0-698.0 m)

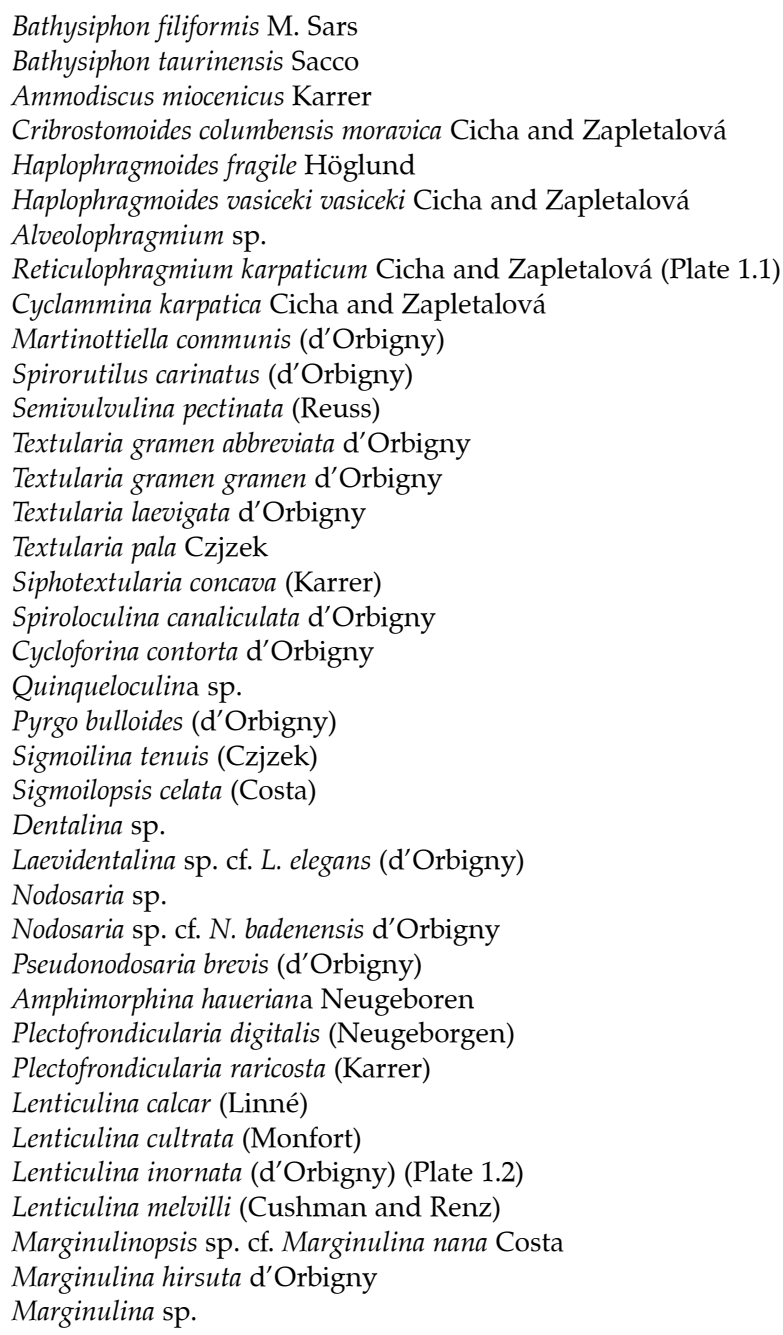


Planularia moravica (Karrer)

Lagena gracilicosta Reuss

Lagena isabella d'Orbigny

Lagena sulcata (Walker and Jakob)

Lagena striata (d'Orbigny)

Favulina hexagona (Williamson)

Guttulina communis (d'Orbigny)

Fissurina obtusa Egger

Fissurina orbignyana Seguenza

Hoeglundia elegans (d'Orbigny)

Globigerina bulloides d'Orbigny (Plate 1.3)

Globigerina concinna Reuss (Plate 1.4)

Globigerina dubia Egger (Plate 1.5)

Globigerina lentiana Rögl

Globigerina praebulloides Blow

Globigerina tarchanensis Subbotina and Chutzieva

Globigerinoides bisphericus Todd

Globigerinoides trilobus (Reuss)

Globoturborotalia ottnangiensis Rögl (Plate 1.6)

Globoturborotalia woodi (Jenkins)

Globigerinella obesa (Bolli)

Bolivina alata (Seguenza)

Bolivina antiqua d'Orbigny

Bolivina dilatata brevis Cicha and Zapletalová

Bolivina dilatata dilatata Reuss

Bolivina fastigia Cushman

Bolivina hebes MacFayden

Bolivina matejkai Cicha and Zapletalová

Bolivina plicatella Cushman

Bolivina pokornyi Cicha and Zapletalová

Bolivina scalprata miocenica MacFayden

Bolivina scalprata muscosa Cicha and Zapletalová

Bolivina scalprata retiformis Cushman

Bolivina simplex Phleger and Parker

Bolivina viennensis Marks

Cassidulina laevigata d'Orbigny

Globocassidulina oblonga (Reuss)

Bulimina elongata d'Orbigny

Bulimina striata d'Orbigny

Bulimina subulata (Cushman and Parker)

Globobulimina pupoides (d'Orbigny)

Preglobobulimina pyrula (d'Orbigny)

Pappina breviformis (Papp and Turnovsky)

Pappina parkeri (Karrer)

Pappina primiformis (Papp and Turnovsky) (Plate 1.7)

Uvigerina acuminata Hosius

Uvigerina graciliformis Papp and Turnovsky (Plate 1.8)

Uvigerina sp. cf. U. rudligensis Papp

Uvigerina sp.

Uvugerina semiornata d'Orbigny

Angulogerina angulosa (Williamson)

Trifarina bradyi Cushman 


\author{
Reusella spinulosa (Reuss) \\ Coryphostoma digitalis (d'Orbigny) \\ Coryphostoma sinuosa (Cushman) \\ Fursenkoina acuta (d'Orbigny) \\ Stilostomella adolphina (d'Orbigny) \\ Stilostomella scripta (d'Orbigny) \\ Stilostomella sp. \\ Valvulineria complanata (d'Orbigny) \\ Rosalina sp. cf. R. semiportata (Egger) \\ Cibicidoides lopjanicus (Mjatlukova) \\ Cibicidoides ornatus (Cicha and Zapletalová) \\ Cibicidoides pachyderma (Rzehak) \\ Cibicidoides ungerianus (d'Orbigny) \\ Cibicidoides vortex (Segzenza) \\ Biapertorbis biaperturatus Pokorny \\ Asterigerinata planorbis (d'Orbigny) \\ Nonion commune (d'Orbigny) (Plate 1.9) \\ Protelphidium sp. \\ Melonis pompilioides (Fichtel and Moll) \\ Pullenia bulloides (d'Orbigny) \\ Charltonina sp. \\ Heterolepa dutemplei (d'Orbigny) (Plate 1.10) \\ Gyroidina neosoldanii Brotzen \\ Hanzawaia boueana (d'Orbigny) \\ Hanzawaia sp. \\ Ammonia viennensis Rögl \\ Asteroammonia sp. \\ Porosononion granosum (d'Orbigny) \\ Elphidium fichtelianum (d'Orbigny) \\ Elphidium ortenburgense (Egger) (Plate 1.11) \\ Elphidium subtypicum Papp (Plate 1.12) \\ Elphidium ungeri (Reuss)
}

